\title{
MORPHOLOGICAL SUBSTANTIATION OF THE USE OF LASER AND LED IRRADIATION IN EMERGENT TREATMENT OF ULCER COMPLICATIONS
}

\author{
I.M. Baybekov \\ Dr. Sci. (Med.), Prof., Head of the laboratory \\ Laboratory of Pathological Anatomy \\ Republican Specialized Center of Surgery named after \\ academician $V$. Vakhidov \\ 10 Farkhad St., Tashkent, 100115, Uzbekistan \\ tel.: +998 (71) 277-92-57 \\ e-mail: baibekov@mail.ru \\ ORCID 0000-0003-0587-3188
}

\author{
D.T. Pulatov \\ Senior Researcher \\ Department of Emergency Surgery \\ Republican Scientific Center of Emergency Medical Care \\ 2 Farkhad St., Tashkent, 100107, Uzbekistan \\ tel.: +998 (71) 150-46-00 \\ e-mail: baibekov@mail.ru
}

The structural basis of ulcer perforation and bleeding was determined, based on morphological evaluation of gastroduodenal ulcers. The effects of low-intensive laser irradiation LILI and LED irradiation on pathomorphosis of ulcers were studied. It was found that the local phototherapy with LILI and LED increases the relative fraction volume - RFV of fibroblasts and connective tissue fibers, reduces RFV of cell-free zones, which contributes to "strengthening" of the ulcer walls and prevents their perforation. These same photo-influences lead to an increase of RFV of blood vessels, indicating inappropriateness of their use for local phototherapy in bleeding ulcers.

Key words: gastroduodenal ulcers, morphology, perforation, bleeding, laser and LED irradiation.

\section{МОРФОЛОГІЧНЕ ОБГРУНТУВАННЯ ВИКОРИСТАННЯ ЛАЗЕРНОГО ТА СВІТЛОДІОДНОГО ВИПРОМІНЮВАННЯ В ЛІКУВАННІ УРГЕНТНИХ УСКЛАДНЕНЬ ВИРАЗКОВОЇ ХВОРОБИ}

\section{І.М. Байбеков ${ }^{1}$, Д.Т. Пулатов ${ }^{2}$}

${ }^{1} A T$ «Республіканський спеціалізований центр хірургї імені академіка В.Вахідова», Міністерство охорони здоров'я Республіки Узбекистан, м. Ташкент, Республіка Узбекистан;

${ }^{2}$ Республіканський науковий центр екстреної медичної допомоги, м. Ташкент, Республіка Узбекистан

На підставі морфологічної оцінки гастродуоденальних виразок встановлено структурні основи ïx прободіння і виразкових кровотеч. Вивчено вплив на патоморфоз виразок низькоінтенсивного лазерного - НIЛВ і світлодіодного випромінювання - LED. Виявлено, що локальна фототерапія 3 використанням HIЛB i LED збільшує відносну об'ємну частку - ВОЧ фібробластів і сполучнотканинних волокон, знижує ВОЧ безклітинних зон, що сприяє «зміцненню» стінок виразок, і попереджає їх прободіння. Ці ж фотовпливи призводять до збільшення ВОЧ кровоносних судин, що вказує на недоцільність їх використання для локальної фототерапії при виразкових кровотечах.

Ключові слова: гастродуоденальні виразки, морфологія, прободіння, кровотечі, лазерне і світлодіодне випромінювання

\section{МОРФОЛОГИЧЕСКОЕ ОБОСНОВАНИЕ ИСПОЛЬЗОВАНИЯ ЛАЗЕРНОГО И СВЕТОДИОДНОГО ИЗЛУЧЕНИЯ В ЛЕЧЕНИИ УРГЕНТНЫХ ОСЛОЖНЕНИЙ ЯЗВЕННОЙ БОЛЕЗНИ}

\section{И.М. Байбеков ${ }^{1}$, Д.Т. Пулатов ${ }^{2}$}

${ }^{1}$ АО «Республиканский специализированный центр хирургии имени академика В. Вахидова»,

Министерство здравоохранения Республики Узбекистан, г. Ташкент, Республика Узбекистан;

${ }^{2}$ Републиканский научный центр экстренной медицинской помощии, г. Ташкент, Республика Узбекистан

На основании морфологической оценки гастродуоденальных язв установлены структурные основы их прободения и язвенных кровотечений. Изучено влияние на патоморфоз язв низкоинтенсивного лазерного - НИЛИ и светодиодного излучения - LED. Выявлено, что локальная фототерапия c использованием НИЛИ и LED увеличивает относительную объёмную долю-ООД фибробластов и соединительнотканных волокон, снижает ООД бесклеточных зон, что способствует «укреплению» стенок язв, и предупреждает их прободение. Эти же фотовоздействия приводят к увеличению ООД кровеносных сосудов, что указывает на нецелесообразность их использования для локальной фототерапии при язвенных кровотечениях.

Ключевые слова: гастродуоденальные язвы, морфология, прободения, кровотечения, лазерное и светодиодное излучение 


\section{Background and objectives}

Marked trend in decrease of the number of patients with peptic ulcer disease requiring surgical treatment, due to the development of the "gold standard" of drug therapy of this disease, based on the discovering etiological and pathogenetic role of Helicobacter pylori. [1-4]

Despite this, peptic ulcer disease - PUD continues to be one of the most urgent problems of surgery. Prevalence of PUD among adult population comprises 6-10\%. A significant proportion of patients with PUD need emergent treatment. This is especially true of its complicated forms. [2,3,5-12]

Various types of photo-influencing such as local irradiation of ulcers, using low-intensive lasers - LIL, and more recently, LED (Light Emitting Diode) light and intravascular laser irradiation of blood - ILIB widely used in gastroenterology, including complex treatments of urgent complications of ulcers. [1,7,13-18]

However, morphological grounds of expediency of using particular types of photo-influencing and methods for their use in the treatment of urgent complications of ulcers are not clear enough.

This has determined the objectives of study: to provide morphological justification for reasonability of using LIL and LED in complex treatment of bleeding and perforations of gastroduodenal ulcers.

\section{Material and Methods}

The followings were studied with aid of light, electron microscopy and stereomorphometry: uncomplicated gastric ulcers -20 , perforated gastric ulcers -20 , bleeding gastric ulcers before and after phototherapy $-18 ; 10$ uncomplicated and 14 bleeding duodenal ulcers. Along with this, we also considered the presence of so-called microcollectors in ulcer walls and peri-ulcerous areas, which are the structural basis of persistent ulcers. (Scient. discovery: "The phenomenon of infiltration of gastric juice through defect in gastric and duodenal wall in patients with PUD" priority date 6.02.1991 № OT-12119).

The tissue samples used for morphological study were excised from the edges of ulcers during surgery. After the course of phototherapy biopsy samples were obtained during fibrogastroduodenoscopy.

Archival microscopic specimens of pathology laboratory of RSCS after acad. V.Vakhidov were used for studying uncomplicated ulcers.

For light microscopy, tissue was fixed in $10-12 \%$ formalin solution on phosphate buffer by Lilly. Paraffin sections were stained with hematoxylin-eosin.

For transmission electron microscopy (TEM), tissue samples were fixed with $2.5 \%$ glutaraldehyde solution on phosphate or cacodylate buffer, after dehydration in alcohol and acetone embedded in eponaraldite mixture. Ultrathin sections were obtained on ultratome "Ultracut", contrasted in "Ultrostainer" and examined with Hitachi H-600 electron microscope.

For scanning electron microscopy (SEM), the specimens, after the above-described fixation and dehydration were then dried by critical point drying in HCP-2, after which gold sputtered with IB-2 and examined in microscope JEOL JSM-6010LV and Hitachi- S405.

Stereomorphometric studies were carried out according to G. Avtandilov. [19] This method was modified and adapted for morphometry of objects on the computer screen with a transparent film, containing marks potted on it. For purposes of studying the discrete structures each cell was lined out 100 marks. Linear structures were studied by using micrometer bar "OMO" with the scale range of $1000 \mathrm{~mm}$ and a scale division of $0.01 \mathrm{~mm}$, projected on film.

Statistical analysis was performed on a PC with "BS - Statistica" software, as well as MS Excel application.

Epigastric areas in the projection of ulcers were irradiated with laser percutaneously, ("Mustang 017-MCS-PC", magnetic nozzle with magnetic field strength of $50 \mathrm{MLT}$ ), for 5 minutes at $1000 \mathrm{~Hz}$ on daily basis, 5 sessions in total.

Percutaneous LED irradiation was performed with LED set "Barva-Flex/BIR", (12 blue (470 nm) and 12 infrared $(940 \mathrm{~nm})$ emitters, the radiation power of each LED equaling to $5 \mathrm{~mW}$ ) in projection of uncomplicated ulcers, daily for 7-10 min over the time of 5-7 days under conditions of maximum proximity to the skin surface.

\section{Results}

Comparative stereomorphometric studies of uncomplicated gastric ulcers, duodenal ulcers and gastric ulcers complicated by perforation, showed a significant increase in the relative volume fraction - RVF of cell-free zones, thin-walled capillaries and lymph microcollectors (Table 1, Fig. 1.3). Light microscopy as well as SEM and TEM demonstrate presence of $\mathrm{RBC}$ - predominantly pathologic deformed forms, and other blood cells in the lumen of latter (Fig. 1, 3, 4).

A significant increase in RVF of fibroblast is noted after courses of percutaneous exposure of uncomplicated gastric ulcers to LILI and LED, with significant decrease of RVF of microcollectors and intercellular spaces. These changes are accompanied by a pronounced increase in the RVF of blood vessels (Table 1).

Photo-influencing in case of complicated by perforation ulcers have also showed a significant increase of RVF of fibroblasts and blood vessels, reduction of intercellular spaces, lymph vessels and microcollectors (Table 1).

Earlier conducted similar studies of perforated duodenal ulcers showed similar results [15].

Light microscopic and stereomorphometric studies of bleeding gastric and duodenal ulcers demonstrated 
a significant increase in RVF of blood vessels in this type of complication (Table 2, 3, Fig. 2, 3).

RVF of blood vessels in bleeding gastric ulcers increases 5 times, lymphatic vessels 4 times, microcollectors -1.3 times. In duodenal bleeding ulcers RVF of blood vessels increases more than 4 times, lymph capillaries more than 5 times, microcollectors 1.5 times
(Table 1, 2, Fig. 1, 2). It was found that such increase of RVF of blood vessels after courses of phototherapy is also characteristic for uncomplicated gastric and duodenal ulcers (as previously mentioned). This, in our view, indicates the inexpedience of usage of photo-influences in ulcers that are prone to bleeding, i. e. have high RVF of blood vessels and microcollectors.

Cellular composition of fibrinoid necrosis areas and granulation tissue taken from the edges of

Table 1 perforated gastric ulcers and peri-ulcerous areas (in relative volume fraction, \%)

\begin{tabular}{|c|c|c|c|c|c|c|c|}
\hline \multicolumn{2}{|c|}{$\begin{array}{l}\text { Cellular } \\
\text { composition of } \\
\text { stroma }\end{array}$} & $\begin{array}{c}\text { Uncomplicated } \\
\text { ulcers } \\
(n=20)\end{array}$ & $\begin{array}{l}\text { Perforated } \\
\text { ulcers } \\
(n=20)\end{array}$ & $\begin{array}{c}\text { Uncomplicated } \\
\text { ulcers after } \\
\text { LED-therapy } \\
(n=10)\end{array}$ & $\begin{array}{c}\text { Uncomplicated } \\
\text { ulcers after } \\
\text { LILI-therapy } \\
(n=10)\end{array}$ & $\begin{array}{c}\text { Perforative } \\
\text { ulcers after } \\
\text { LED-therapy } \\
(n=10)\end{array}$ & $\begin{array}{c}\text { Perforative } \\
\text { ulcers after } \\
\text { LILI-therapy } \\
(n=10)\end{array}$ \\
\hline \multicolumn{2}{|c|}{ Plasma cells } & $8.0 \pm 0.2$ & $7.4 \pm 0.3$ & $6.8 \pm 0.02$ & $6.5 \pm 0.2^{*}$ & $6.6 \pm 0.2^{*}$ & $6.4 \pm 0.2^{\star \star}$ \\
\hline \multicolumn{2}{|c|}{ Lymphocytes } & $8.8 \pm 0.3$ & $7.6 \pm 0.2$ & $7.5 \pm 0.02$ & $7.2 \pm 0.2$ & $7.2 \pm 0.2$ & $7.0 \pm 0.2^{*}$ \\
\hline \multicolumn{2}{|c|}{ Must cells } & $2.6 \pm 0.1$ & $1.9 \pm 0.1$ & $2.2 \pm 0.1$ & $2.1 \pm 0.1$ & $2.2 \pm 0.1$ & $2.0 \pm 00.1$ \\
\hline \multicolumn{2}{|c|}{ Eosinophils } & $5.0 \pm 0.2$ & $4.8 \pm 0.2$ & $5.1 \pm 0.2$ & $4.9 \pm 0.2$ & $5.1 \pm 0.2$ & $5.0 \pm 0.2^{*}$ \\
\hline \multicolumn{2}{|c|}{$\begin{array}{l}\text { Segmented } \\
\text { neutrophils }\end{array}$} & $2.1 \pm 0.1$ & $1.8 \pm 0.2$ & $1.5 \pm 0.1$ & $1.4 \pm 0.1$ & $1.4 \pm 0.1$ & $1.3 \pm 0.1$ \\
\hline \multicolumn{2}{|c|}{ Macrophages } & $0.9 \pm 0.1$ & $1.0 \pm 0.1$ & $0.8 \pm 0.1$ & $0.9 \pm 0.1$ & $0.8 \pm 0.1$ & $0.8 \pm 0.1$ \\
\hline \multicolumn{2}{|c|}{ Fibroblasts+fibers } & $6.6 \pm 0.2$ & $2.0 \pm 0.2^{*}$ & $10.9 \pm 0.2^{\star \star}$ & $11.9 \pm 2^{\star \star}$ & $11.5 \pm 2^{\star \star}$ & $12.4 \pm 2^{\star \star}$ \\
\hline \multirow{2}{*}{ Vessels } & blood & $1.2 \pm 0.02$ & $1.2 \pm 0.02$ & $6.2 \pm 0.2^{\star \star}$ & $7.0 \pm 0.02$ & $6.2 \pm 0.02$ & $6.4 \pm 0.02$ \\
\hline & lymphatic & $0.7 \pm 0.03$ & $1.5 \pm 0.02^{*}$ & $0.5 \pm 0.02$ & $0.5 \pm 0.02$ & $0.5 \pm 0.02$ & $0.5 \pm 0.02$ \\
\hline \multicolumn{2}{|c|}{ Microcollectors } & $8.7 \pm 0.4$ & $10.6 \pm 0.8$ & $7.2 \pm 0.4^{\star \star}$ & $7.0 \pm 0.4^{\star *}$ & $7.3 \pm 0.4^{\star \star}$ & $7.2 \pm 0.4^{\star \star}$ \\
\hline \multicolumn{2}{|c|}{$\begin{array}{l}\text { Intracellular } \\
\text { substance }\end{array}$} & $52.5 \pm 0.9$ & $59.2 \pm 1.0^{\star}$ & $49.4 \pm 0.8^{\star *}$ & $49.2 \pm 0.8^{* *}$ & $49.4 \pm 0.8^{\star \star}$ & $49.2 \pm 0.8^{\star *}$ \\
\hline \multicolumn{2}{|c|}{ Others } & $2.9 \pm 0.1$ & $1.0 \pm 0.2$ & $1.9 \pm 0.1$ & $1.4 \pm 0.1$ & $1.8 \pm 0.1$ & $1.8 \pm 0.1$ \\
\hline
\end{tabular}

* reliable in relation to uncomplicated ulcers $(p<0,05)$

** reliable in relation to perforated ulcers $(p<0,05)$

Table 2

Cellular composition of fibrinoid necrosis areas and granulation tissue from bleeding gastric ulcers (in relative volume fraction, \%)

\begin{tabular}{|c|c|c|c|}
\hline \multicolumn{2}{|c|}{ Cellular composition of stroma } & Uncomplicated ulcers $(n=20)$ & Bleeding ulcers $(n=18)$ \\
\hline \multicolumn{2}{|c|}{ Plasma cells } & $8.0 \pm 0.2$ & $7.4 \pm 0.3$ \\
\hline \multicolumn{2}{|c|}{ Lymphocytes } & $8.8 \pm 0.3$ & $8.9 \pm 0.2$ \\
\hline \multicolumn{2}{|c|}{ Mast cells } & $2.6 \pm 0.1$ & $4.2 \pm 0.1^{*}$ \\
\hline \multicolumn{2}{|c|}{ Eosinophils } & $5.0 \pm 0.2$ & $6.0 \pm 0.2$ \\
\hline \multicolumn{2}{|c|}{ Segmented neutrophils } & $2.1 \pm 0.1$ & $3.2 \pm 0.2$ \\
\hline \multicolumn{2}{|c|}{ Macrophages } & $0.9 \pm 0.1$ & $2.2 \pm 0.1^{*}$ \\
\hline \multicolumn{2}{|c|}{ Fibroblasts + fibers } & $6.6 \pm 0.2$ & $6.2 \pm 0.2$ \\
\hline \multirow{2}{*}{ Vessels } & blood & $1.2 \pm 0.02$ & $5.9 \pm 0.3^{*}$ \\
\hline & lymphatic & $0.5 \pm 0.03$ & $2.0 \pm 0.1^{*}$ \\
\hline \multicolumn{2}{|c|}{ Microcollectors } & $9.9 \pm 0.4$ & $12.8 \pm 0.8^{\star}$ \\
\hline \multicolumn{2}{|c|}{ Intercellular substance } & $52.5 \pm 0.9$ & $38.4 \pm 1.0^{*}$ \\
\hline \multicolumn{2}{|c|}{ Others } & $1.9 \pm 0.1$ & $2.8 \pm 0.2$ \\
\hline
\end{tabular}

* reliable in relation to uncomplicated ulcers $(p<0.05)$ 
Cellular composition of fibrinoid necrosis and granulation tissue from duodenal ulcers

Table 3 (in relative volume fraction, \%)

\begin{tabular}{|c|c|c|c|}
\hline \multicolumn{2}{|c|}{ Cellular composition of stroma } & Uncomplicated ulcers $(n=10)$ & Bleeding ulcers $(n=14)$ \\
\hline \multicolumn{2}{|c|}{ Plasma cells } & $8.1 \pm 0.2$ & $7.2 \pm 0.3$ \\
\hline \multicolumn{2}{|c|}{ Lymphocytes } & $8.9 \pm 0.3$ & $10.9 \pm 0.2$ \\
\hline \multicolumn{2}{|c|}{ Mast cells } & $2.4 \pm 0.1$ & $4.4 \pm 0.1^{*}$ \\
\hline \multicolumn{2}{|c|}{ Eosinophils } & $5.1 \pm 0.2$ & $6.6 \pm 0.2$ \\
\hline \multicolumn{2}{|c|}{ Segmented neutrophils } & $1.8 \pm 0.1$ & $3.0 \pm 0.2^{*}$ \\
\hline \multicolumn{2}{|c|}{ Macrophages } & $0.8 \pm 0.1$ & $1.9 \pm 0.1^{*}$ \\
\hline \multicolumn{2}{|c|}{ Fibroblasts+fibers } & $6.4 \pm 0.2$ & $7.2 \pm 0.2$ \\
\hline \multirow{2}{*}{ Vessels } & blood & $1.6 \pm 0.02$ & $7.0 \pm 0.3^{*}$ \\
\hline & lymphatic & $0.4 \pm 0.03$ & $2 \pm 0.1^{*}$ \\
\hline \multicolumn{2}{|c|}{ Microcollectors } & $8.4 \pm 0.4$ & $12.6 \pm 0.8^{*}$ \\
\hline \multicolumn{2}{|c|}{ Intercellular substance } & $53.4 \pm 1.0$ & $34.3 \pm 1.0^{\star}$ \\
\hline \multicolumn{2}{|c|}{ Others } & $2.7 \pm 0.1$ & $2.9 \pm 0.2$ \\
\hline
\end{tabular}

* reliable in relation to uncomplicated ulcers $(p<0.05)$

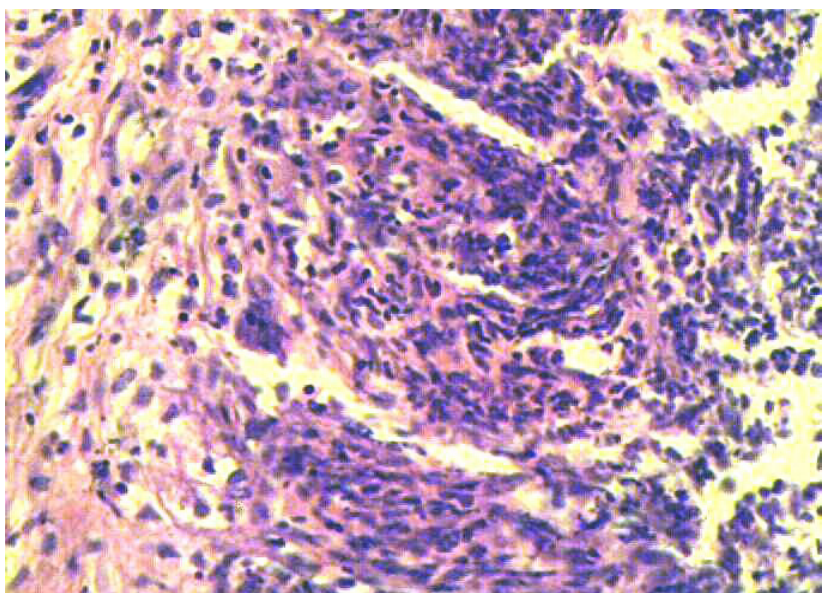

Fig. 1. Well discernable microcollectors with cells in their lumen and microvessels. Edge of bleeding ulcer. H\&E $10 \times 40$

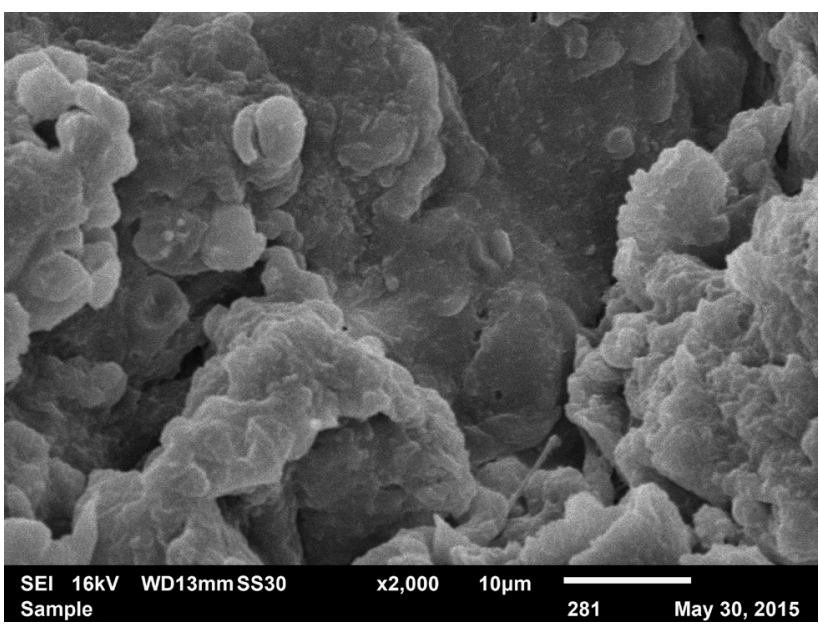

Fig. 3 Opening of microcollectors with RBC in their lumen. Edge of bleeding gastric ulcer. SEM x 2000

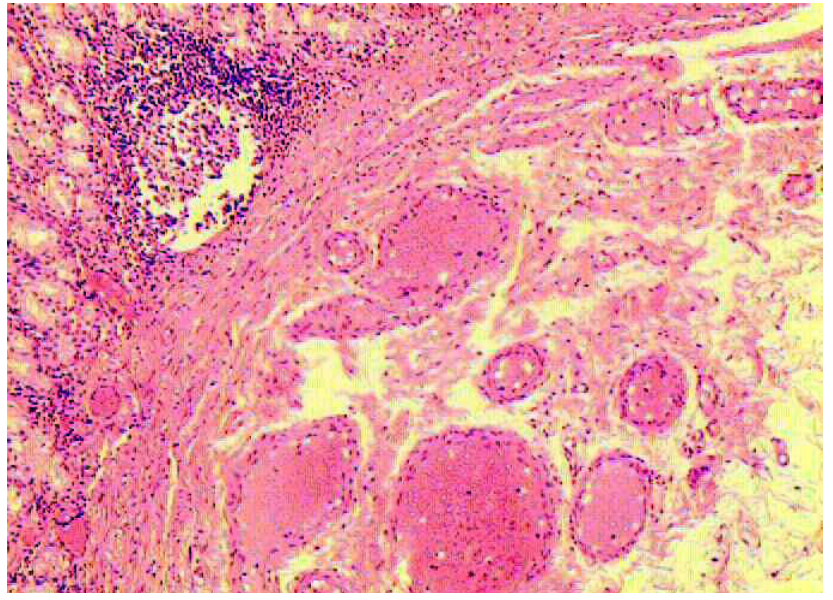

Fig. 2. Predominance of blood vessels. Cell-free zones and dilated lymphatic capillaries. Edge of bleeding ulcer. Г-Э $10 \times 10$

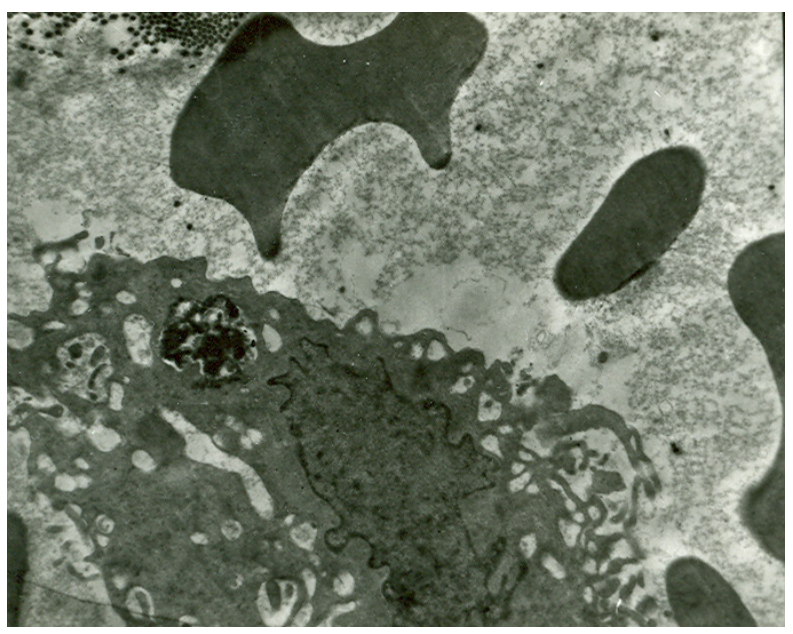

Fig. 4. Deformed RBC in cell-free spaces (microcollectors) from an edge of bleeding duodenal ulcer. TEM $\times 7500$ 


\section{Discussion}

Laser, and in recent years LED light are widely used in practically all branches of medicine. Moreover, studies show that, as a rule, the efficiency of LILI is comparable to LED. [1,13-15,18] Gastroenterology, in this respect, is no exception. In particular, various kinds of photoexcitation widely used in treatment of peptic ulcers, and primarily, uncomplicated gastroduodenal ulcers. [1,15] Carried out, in the mid 90-ies of the last century, studies have shown positive effects of LILI on the healing of uncomplicated ulcers. The morphological studies have established that the structural basis of such positive effects lie in reduction of inflammatory changes, stimulation of cell proliferation and differentiation, provided by improvement of microcirculation due to increase of RVF of blood vessels and fibroblasts. [1]

Less frequently LILI and LED are exploited in the treatment of complicated ulcers and, above all, the so-called acute complications. This is partly due to the lack of clear criteria, and above all the morphological, to justify the use of phototherapy in the treatment of such urgent complications of gastroduodenal ulcers as bleeding and perforation.

The conducted comparative stereomorphometric study of uncomplicated gastroduodenal ulcers and ulcers, complicated by perforation and bleeding, revealed some structural features that, in our view, should be considered in using phototherapy for urgent complications of gastroduodenal ulcers.

In this way, perforation of ulcers is associated with substantial increases of RVF of structureless areas and thin-walled lymphatic vessels. It is also accompanied by a marked reduction of fibroblasts and fibrous components. Bleeding ulcers are, on the other hand, associated with significant increase of RVF of blood vessels. Not the least of the factors in the emergence and persistence of gastroduodenal ulcers is amount of so-called microcollectors. [20,21]

Phototherapy of uncomplicated ulcers as with LILI as well as LED, results in a significant reduction of RVF of cell-free zones, thin-walled capillaries and lymph microcollectors, with increase of RVF of fibroblasts, fibrous structures and blood vessels. The same trend was observed in perforated ulcers.

This suggests that the use of local phototherapy can be useful in perforated ulcers.

An increase of RVF of blood vessels observed after local phototherapy may predispose to bleeding. Therefore, the use of local phototherapy in bleeding ulcer, which is associated with increased RVF of blood vessels, does not seem to be rational. Phototherapy in case of bleeding ulcers can be limited to use of ILIB - an effective mean in correcting red blood cells, the majority of which become deformed and acquire pathologic forms in bleeding. [1,13,14,17]

\section{Conclusions}

1. Perforated ulcers are characterized by high RVF of thin-walled lymph capillaries and cell-free zones; the RVF fibroblasts and fibers becomes reduced, which is a structural basis of this complication. Phototherapy reduces the RVF of acellular zones and increases the RVF of fibroblasts and fibers, which indicates the desirability of its use in the urgent complications.

2. Bleeding ulcers are characterized by the fact that they contain increased RVF of blood vessels. Phototherapy of uncomplicated ulcers leads to an increases of RVF of blood vessels. This implies that the use of photoexcitation in bleeding ulcers is not advisable.

3. The morphological study of biopsies from the edges of ulcers and peri-ulcerous areas should play a decisive role in the administering phototherapy in urgent complications of peptic ulcer disease.

\section{References}

1. Baibekov IM, Nazirov FG, editors. Morfologicheskie aspektyi lazernyih vozdeystviy (na hronicheskie yazvyi i pechen) [Morphological aspects of laser influences (on chronic ulcers and liver)]. Tashkent: Ibn Sina Publ.; 1996. 207 p. (in Russian)

2. Ivashkin VT. Gastroenterologiya [Gastroenterology]. Moscow: GEOTAR-Media; 2013. 704 p. (in Russian)

3. Ivashkin VT. Gastroenterologiya. Natsionalnoe rukovodstvo [Gastroenterology National guidelines]. Moscow: GEOTAR-Media; 2014. 480 p. (in Russian)

4. Zuo Jian-sheng, Xu Ke-cheng. The treatment and follow-up of the peptic ulcer associated with Helicobacter pylori.Ital J Gastroenterol. 1991;23(9):296.

5. Astashov VL, Kalinin AV. Bleeding from chronic gastroduodenal ulcers: diagnosis, tactics and surgical treatment. Klin. perspektivyi gastroenterol., gepatologii [Clin. Prospects of Gastroenterololgy and Hepatology]. 2002;1:16-23. (in Russian)

6. Afendulov SA, Zhuravlev GYu. Hirurgicheskoe lechenie bolnyih yazvennoy boleznyu [Surgical treatment of patients with peptic ulcer]. Moscow: GEOTAR-Media; 2008. 336 p. (in Russian)

7. Korobov AM, Korobov VA, Lesnaya TA. Fototerapevticheskie apparatyi Korobova serii "Barva" [Korobov's phototherapeutical devices of "Barva" series]. Harkiv: Petrov VV Publ.; 2010. 176 p. (in Russian)

8. Barkun A, Bardou V, Marshall JR, Nonvariceal Upper GI Bleeding Consensus Conference Group. Consensus Recommendations for Managing Patients with Nonvariceal Upper Gastrointestinal Bleeding. Ann Intern Med. 2003; 139(10):843-57.

9. De Caestecker J. Upper Gastrointestinal Bleeding: Surgical Perspective. Medicine from WebMD, Article Last Updated. 2006 Apr;11:89-91.

10. Hillakivi T, Lang A, Tein A. Evaluation of risk factors for mortality in surgical treated perforated duodenal ulcer. Hepatogastroenterology. 2000;47(36):1765-8.

11. Noguiera C, Silva AS, Santos JN, Silva AG, Ferreira J, Matos E, et al. Perforated peptic ulcer: main factors of morbidity and mortality. World J Surg. 2003 Jul;27(7):782-7.

12. Kang JY, Elders A, Majeed A, Maxwell JD, Bardhan KD. Recent trends in hospital admissions and mortality 
rates for peptic ulcer in Scotland 1982-2002 Aliment Pharmacol Ther. 2006 Jul 1;24(1):65-79.

13. Baibekov IM, Mavlyan-Hodzhaev RSh, Erstekis AG, Moskvin SV. Eritrotsityi v norme, patologii i pri lazernyih vozdeystviyah [Red blood cells in norm, pathology and in laser irradiation]. Tver: Triada Publ.; 2008. 255 p. (in Russian)

14. . Baibekov IM, Ibragimov AF, Baibek-Palmos MI. Lazernyie vozdeystviya na kozhu i eritrotsityi v norme i patologii [Laser influences on skin and red blood cells in health and disease]. Saardrucken: LAMBERT Academic Publ.; 2014. 362 p. (in Russian)

15. Baibekov IM, Pulatov DT. Effect of LED apparatus "Barva-Flex/SIK" on morphology of duodenal ulcers in terms of prevention of perforation. Fotobiol. ta fotomed. [Photobiol. and Photomed.]. 2014;12(3, 4):49-53. (in Russian)

16. Heinz AV, Moskvin SV, Azizov GA. Vnutrivennoe lazernoe obluchenie krovi [Intravenous laser irradiation of blood]. Moscow: Triada Publ.; 2006. 144 p. (in Russian)

17. Heinz AV, Moskvin SV. New technologies of intravenous laser irradiation of blood, "ILIB UVIB" and "ILIB-405".
Materialyi nauch.-prakt. konf. s mezhdunar. uch. Lazernaya meditsina XXI veka [Materials of sc.-pract. conf. with internat. partic. Laser Medicine of the XXI century]; 2009 June 9-10; Moscow. p. 71. (in Russian)

18. Tuner J, Hode L. The New Laser Therapy Handboor. Grängesberg: Prima book. 2010. 849 p.

19. Avtandilov GG. Problemyi patogeneza i patologoanatomicheskoy diagnostiki v aspektah morfometrii [Problems of pathogenesis and morphologic diagnosis in aspects of morphometry]. Moscow: Medicine Publ.; 1984. 436 p. (in Russian)

20. Hadzhibaev AM, Eshbekov M, Baibekov IM, Mirzakhmedov BM. Possible mechanisms of morphogenesis of chronic ulcers of stomach and duodenum. Med. zhurn. Uzbekistana [Med. Jour. of Uzbekistan]. 1992;9-10:158. (in Russian)

21. Hadzhibaev AM, Malikov YuR, Melnyik IV. Surgical tactics in the treatment of recurrent ulcer bleeding. Review of literature. Byull. assots. vrachey Uzbekistana [Bull. of physicians of Uzbekistan]. 2005;3:42-5. 